Apuntes Universitarios, 2021: 11(1), enero-marzo

ISSN: 2304-0335 DOI: https://doi.org/10.17162/au.v11i1.568

\title{
Representaciones políticas y legales de las sinergias entre el estado y la religión
}

\section{Political and Legal Representations of the Synergies between the State and the Religion}

Dina V. Alontseva ${ }^{1}$, Arsen V. Akopyan ${ }^{2}$, Valentina A. Matvienko ${ }^{3}$, Irina A. Zaitseva ${ }^{4}$, Alexander E. Krikunov ${ }^{5}$

Bunin Yelets State University, Yelets, Russia ${ }^{12345}$

iD ORCID ID: https://orcid.org/0000-0003-2486-92481

ORCID ID: https://orcid.org/0000-0001-7005-21382

ORCID ID: https://orcid.org/0000-0001-5384-25333

ORCID ID: https://orcid.org/0000-0001-6405-6140

ORCID ID: https://orcid.org/0000-0001-9632-5106

Recibido: 03 de julio de 2020

Aceptado 07 de octubre de 2020

\section{Resumen}

El objetivo del presente artículo es considerar los estudios de los científicos sobre el poder y la sinergia religiosa en las relaciones entre el Estado y la religión como institución social. El método científico dialéctico general permitió a los autores considerar el problema de la reforma de la legislación religiosa en la Federación de Rusia en la etapa actual; demostrar los cambios en la legislación religiosa de la Federación de Rusia en función de una combinación de factores internos y externos que la afectan. Los resultados del estudio permitieron a los autores sacar las siguientes conclusiones: la institución de la religión en el mundo moderno no puede evitar la participación en el arreglo de los procesos políticos. Por tanto, es necesario desarrollar un mecanismo de implementación de los principios constitucionales para los vínculos entre el Estado y la Iglesia.

Palabras clave: estado, iglesia, religión, desarrollo espiritual, Rusia..

\begin{abstract}
The aim of the article is devoted to analyzing political and legal representations of the concepts of relations between two public institutions: the Church and the State, suggested by modern academics. Emphasis has been placed on the fact that the model of the religious and power synergy has been transformed by the existing system of values and is legally enshrined. The general dialectical scientific method enabled the authors to consider the problem of reformation of the religious legislation in the Russian Federation at the present stage; to demonstrate the changes in the religious legislation of the Russian Federation depending on a combination of internal and external factors affecting it. The results of the study let the authors draw the
\end{abstract}


following conclusions: the institution of religion in the modern world cannot avoid participation in settlement of political processes. Therefore, it is necessary to develop a mechanism for implementation of constitutional principles for the ties between the State and the Church.

Keywords: state, church, religion, spiritual development, Russia.

\section{Introduction}

The beginning of the XXI century is characterized as a difficult and challenging time in all areas of society. It also includes the spiritual area, as over the past decades the process of the revival of Christianity has been outlined. Religious norms and Church dogmata are becoming fundamental in the life of the population. However, the atheistic era of the last century does not fully allow the formation of the spiritual revival of Russia. And, nowadays, the spiritual and moral crisis in the mindset of the country's citizens has not yet been overcome. Russian lawyer and philosopher I.A. Ilyin defined the relationship between the state and the Church: "The Church and the state are mutually alien - in establishment, in spirit, in dignity, in purpose, and in mode of action. The state, which tries to appropriate the power and dignity of the Church, creates blasphemy, sin and vulgarity. The Church that tries to usurp the power and sword of the state loses its dignity and changes its purpose... The Church should not take the sword - not for the propagation of faith, not for the execution of a heretic or a villain, not for war. In this sense, the Church is "apolitical"; the task of politics is not its task, the means of politics are not its means; the rank of politics is not its rank" (Ilyin, 1993). According to A. Nikolin, the state from the point of view of the Church is not only a means of organizing the life of the people, but at its core it is "a Union of spiritually solidary or spiritually co-belonging people, Nations, peoples" (Nikolin, 1997). The State and the Church must become the fundamental elements in the revival of Russian people's spirituality. As modern scholars have noted, "the Church as an organization should not participate in politics, but in a State governed by the rule of law, there should be no obstacles to uniting citizens according to religious principles of the world outlook" (Alontseva, 2011).

Patriarch Kirill of Moscow and all Russia stressed in one of his addresses: "we all enjoy freedom - such as has not been in the entire history of the Russian Church. We determine what the Church needs, and no one interferes in the decision-making of Church Councils, synods or hierarchs. This freedom is given to us as a kind of respite - we must be prepared for the fact that something may change in the future" (Patriarch Kirill, 2012). The Church remains loyal to the state and its authorities. But it has certain limits. If the government forces Orthodox believers to deviate from the faith and their Church, as well as to "sinful, spiritual acts, the Church must refuse to submit to the state" (Archpriest Vladislav Tsypin, 2001). According to 
Russian President Vladimir Putin, "If we are talking about the separation of Church and state, then in modern conditions we should talk about a different content of this secularism, and it should consist in the fact that a completely different regime of relations should be established between the state and religious organizations - a regime of partnership, mutual assistance and support" (Putin, 2012).

The modern value system has transformed the model of the State and Church relations, giving it legal expression in the regulatory acts of the established systems of the law. As a rule, the constitutions of most democratic States enshrine the principle of the "secularism" of the State and Church relations, or separate laws establish the principle of the "autonomy" of religious organizations in the State system.

The following circumstances dictated the choice of this research topic. Firstly, the State and the Church are the two social institutions that have accompanied each other throughout the development of the statehood, making a considerable impact, and trying to defend their superiority. Secondly, the models of the state-religious relations currently have a doctrinal component, based on the world outlook of scholars. Thirdly, international law obliges the states to apply the norms of international law in regulating the relations between the State and the Church. Fourth, in light of the loss of traditional moral values, it is necessary to form a unified system of legislation regulating legal relations in the religion and develop a strategy for the development of state-religious ties in the Russian Federation. Fifth, to streamline the relations between the State and the Church, it is necessary to develop the most optimal model for such a tandem. However, there is no consensus on the optimal model of the State-Church relations among legal scholars.

\section{Literature review}

Both domestic and foreign scientists address the problem of searching for the most optimal model of the State and Church relations. Among Russian researchers, there are G.A. Vydrina (2018), G.A. Vasilevich, N.M. Kondratovich, L.A. Prikhodko (2006), and O.A. Novikov (2009). Recalling foreign academics, we should mention J.J. Corke-Webster (2019), S. White (2019), L.F. Mantilla (2019), etc.

However, at present, foreign scholars are studying the Catholic tradition and its influence on developing the State and religious relations both in countries with a Catholic outlook and in the entire international community. The most outstanding works, in our opinion, are those of J. J. Corke-Webster (2019), who looks at the State-Church relations from a historical retrospective and for their anchoring in the first, ancient sources of Law. S. White (2019) looks at the Church-State relations through the prism of the religiousness of citizens and 
their religious activity. L.F. Mantilla (2019) takes the position on the religion's role in shaping the state policy on religion and mobilizing public consciousness on religious preferences. Western colleagues, in contrast to Russian scientists, do not conduct research of the actual State and Church relations; they consider religion to be identified with the state policy and consider it to be its direct component.

Russian scientists G.A. Vydrina (2018), G.A. Vasilevich, N.M. Kondratovich, L.A. Prikhodko (2006), and O.A. Novikov (2009), unlike their foreign colleagues, are engaged in the research on different concepts of the State and Church relations in order to determine their most optimal and reasonable variant taking into account the interests of both the State and the institute of religion.

G. A. Vydrina (20 considers the State-confessional relations from the standpoint of "separation (dividing), cooperational and identificational" models of the State-confessional relations (Vydrina, 2011). Constitutional scientists: G. A. Vasilevich, N. M. Kondratovich, L. A. Prikhodko (Kondratovich, Prikhodko, 2006) distinguish such models of relations between the State and the Church as: the State (official) religion; legal recognition of the Church by the State; complete separation of the Church and the State. Y. V. Tkachenko discusses the "confessional neutrality of the State and the power" (Tkachenko, 2000).

\section{Materials and methods}

The methodological basis of the study comprises of general scientific, particular and special methods of cognition. The general scientific dialectical method allowed us to consider the problem of relations between the State and the Church at the present stage, to substantiate the advantages and disadvantages of various approaches to the study of this issue. It also enabled us to demonstrate the changes in Russian legislation regulating these relations depending on the totality of internal and external factors affecting it. With the help of formal logic methods, the author described transformations in the state-religious relations at the present stage and identified regulatory imperfections (Alontseva, 2019). Methods of scientific knowledge are used to conduct a study of current legislation to determine its compliance with the problem in question (Alontseva, 2019; Novikov, 2009). For the purpose of correlation of various legal norms in the article, the comparative-legal and formal-legal methods are used (Vydrina, 2018; Vasilevich, Kondratovich, and Prikhodko, 2006). The use of a combination of different methods has made it possible to solve the set of tasks and achieve the stated goal.

The method of the substantial analysis ensures the completeness, reliability, and consistency of the data obtained in the generalization process. The use of predictive methods helps to identify the trends in the development of the object studied and to provide a vision of 
possible positive or negative consequences of implementing the provisions of Russian religious legislation. The use of qualitative research methods (analysis and generalization, comparison, modeling, etc.) is driven by the need to formulate hypotheses and productive ideas, as well as by the desire to understand and explain the already available data.

\section{Results}

Based on the research that has been carried out, the authors have achieved the following results:

1. In the legal systems of modern states, the principle of "secularism" of the state, which defines the legal status of relations between the State and the Church, is enshrined as one of the fundamental principles. In the countries of the Catholic tradition, relations between the State and the institution of religion are built on the basis of a concordat. The unifying conditions for interaction between the State and the Church in all democratic States are: the freedom of conscience (religion), the State's protection of religious organizations and the rights of believers. However, the fundamental nature of the relationship between the State and the Church is the principle of separation of the Church and the State.

2. The interpretations of the state and confessional relations that we have considered, allow us to say that the nature of relations between the power of the State and the institution of religion takes into account the tradition of the State, its cultural heritage, the mentality of the people, the attitude towards religion and its significance for the society of the State machine itself.

3. In the Russian Federation, Russian confessional policy began to take shape with the adoption of the Constitution of Russia and the Federal Law No. 125-FZ (1997). It reflected an attempt to bring the right of citizens to freedom of religion in line with the international legal covenants on human rights: the Universal Declaration of Human Rights, the Charter of Paris for a New Europe, the UN General Assembly Declaration on the Elimination of All Forms of Intolerance and Discrimination Based on Religion or Belief (The Federal Law No 125-FZ, 1997). Every citizen allowed to determine their personal attitude towards religion, that is, the freedom of conscience.

4. Freedom of conscience is a fundamental, inalienable human freedom, which is, in essence, a vector for forming the most optimal model of the relations between the State and the Church. As an independent, historically established phenomenon, it represents an opportunity for a person to choose moral guidelines and behave in accordance with them. Freedom of conscience is a universal comprehensive institution, which implies for citizens both the freedom of religious outlook of the "believer" and the atheistic worldview. 
5. Despite the legislative regulation of the State and Church relations in Russia, the modern legal system regulating these relations is fragmentary character. In order to build an optimal system of relations between the State and the Church, it is necessary to develop and adopt a single normative act of the Religious Code or Code of Religious Organizations, which will legalize in detail the whole range of issues related to the State policy in religious affairs. The suggested document should clearly distinguish between the concepts of "denomination" or "traditional religion" and "non-traditional religion" or a "sect," which will make it possible to legalize the status of religion and pseudo-religion at the normative level.

6. Religious values must be reflected not only in legislation, but also in the cultural tradition of our country. It is vital because they are aimed at restoring morality and spiritual integrity, which is especially relevant and necessary in our time of the loss of traditional values and traditions.

7. The system of relations between the State and the Church in our country must acquire the character of cooperation based on a clear division of functions between them, the definition of the powers of each of them, and definition of the principles and forms of relations between religious organizations and state authorities.

\section{Discussion}

In the views of modern scholars, political and legal representations of the relations between power and religion have not found a unified interpretation. The concepts of the State and Church relations suggested by representatives of Russian jurisprudence are similar because the institution of power and religion must coexist in mutual relations, since the development of the state largely depends on the development of the institution of religion.

Throughout the history of the Russian Statehood there was a search for an ideal form of the State-Church relations. Our contemporary, Novikov (2009), highlights the following periods in the developing of the State and Church relations. The first type is the state Church, which existed in Russia until year 1917. The second model assumes separation of the Church from the State, the third presupposes the persecution of religion, the fourth suggests domination of Church over State, the fifth, formulated in the VI century by the Byzantine Emperor Justinian I, speaks about ideal, "symphonic" relations between Church and power: "There are two greatest blessings, the gifts of the mercy of God to men - the priesthood and the kingdom. Each of these blessings given to people is established by God and has its own purpose. But from the same beginning, it manifests itself in unity, in joint activity" (Novikov, 2009).

Supporting Oleg Novikov's position, the author believe that it would be wise to add a dominant component to the model of relations between the State and the Church. 
The beginning of the previous century can be described as the turning point of the Russian State, as a time of fundamental change. The State and Church model of the 1920-s can be described as "dominant," from the Latin term dominium - ownership, domination.

In our opinion, one can describe the modern State and Church model of Russia as the dominant "State and Church". In the Russian Orthodox tradition, a part of the state apparatus, including the Church as a public institution, has very conditional independence, since it is subordinate to the State, which is confirmed by the following circumstances. First, since 2006, the Church, as a non-profit organization, has been obliged to submit monthly financial reports to the Federal Registration Service. Secondly, with regard to religious organizations, Russian legislation provides for a taxation system. According to Article 381 of the Tax Code of the Russian Federation, the Church is exempt from the following taxes: land tax; property tax, which is used for religious purposes; tax on Church rites and sales of Church items (the law states that the Church does not pay value added taxes on the sales of religious items). Thirdly, the clergy in Russia have such documents as a work record book, indicating their position; medical insurance; and a number in the Pension Fund (Individual insurance account number, SNILS).

An existing position is offered by Vydrina (2011), who believes that there are "separational (divided), cooperational and identificational" models of the state and confessional relations. The first model prevails in secular countries operating on the basis of the principle of the Church as an autonomous institution, separate from the state and endowed with functions only in the religious sphere. In particular, they are the following: the control over compliance with the principle of separation of powers and compliance with the national legislation by religious organizations, registration of new religious associations and assistance in their activities, protection of the rights of believers. The co-operative model of the State and Church relations is manifested as a "tandem" of the state and religious organizations in specific areas of interaction, related exclusively to the activities of the denomination. The legal status of the Church as a public institution is regulated by such methods as the legal consolidation of the status of the national ideology for religion, without the establishment of a state religion or without specifying the state or traditional religion, but with the designation of the dominant function of one or more of them, as well as without specifying the dominant function of any denomination.

From a practical point of view, this model of the State and Church relations is possible if the leading confession makes an unequivocal choice favoring freedom of religion. The cooperative model is two-fold, it can be: either structural (a specialized body for the resolution of conflicts of interest is created in the course of interaction between the State and the Church); or 
functional (interaction between the State and the Church takes place without mediation). The essence of the third identification model is based on the system of correlation between the State and the Church. It highlights such forms of interaction as caesare-papism, Papo-caezarism and the "symphony of the authorities".

Constitutional researchers Vasilevich, Kondratovich, and Prikhodko (2006) distinguish such models of relations between the State and the Church as the state (official) religion; legal recognition of the Church by the state; complete separation of the Church and the State, as we have already mentioned. The model where the Church acts as the state (official) religion and receives legal status on a par with the State as an institution of the society and a pillar of the state. The Church is a part of the state machinery as a non-state body that cooperates and interacts with all State institutions, including legislative bodies, since the adoption of regulations relating to its functioning is necessarily coordinated with the Church leadership. Officials of the religious denomination are allowed in all administrative areas of society as representatives. The powers of the State and the Church are distinguished, and the Church has the right to perform legally significant acts, in particular, such as marriage, birth and death registration. Every citizen in such a State is guaranteed the freedom of religion, the exercise of religious cults, observance of religious traditions and religious education rather than secular ones.

The second model of relations between the State and the Church, which relates to the legal recognition of the Church by the State, involves the independence of two public institutions: the State and the Church. State and Church relations are based on the principle of concord - a special agreement defining the legal status of the Church in the State. This system is typical of European States where the Roman Catholic Church can establish relations between secular and spiritual power in Europe. The Concordat with the Vatican is a special agreement which gives the Roman Catholic Church certain legal rights and privileges which other religious organizations do not enjoy.

The third model of Church-State relations is based on the complete separation of the Church and the State. The essence of this model is that the Church, as a public institution, enjoys full autonomy in its legal status, legal regulation of its activities, and competence. The principle of independence is also manifested in relations with the state. Both institutions are financially and legally independent of each other. Citizens are free to choose their confessional affiliation and religious freedom.

As Tkachenko (2000) notes, Western Europe is characterized by a particular type of secular culture characterized by the following features: "confessional neutrality of the state and power, recognition of freedom of religion or denial of religion, recognition of the independence 
of individual consciousness, critical reflection on all areas of the human spirit (religion, politics, science....)".

The Russian Federation is also a supporter of the Church-State separation model, in which the principle of "secularism" is the fundamental constitutional principle of Russian statehood. In our country, there is no officially recognized religion. All religious organizations are separated from the state. As stated in the Federal Law No. 125-FZ (1997), the Russian Federation recognizes a special role in the history of Russia, in the formation and developing of its spirituality and culture, but also respects "Christianity, Islam, Buddhism, Judaism and other religions that are an integral part of the historical heritage of the peoples of Russia". Having analyzed the legislation of the Russian Federation regulating the State and Church relations, it is necessary to draw the attention of our legislator to the need to systematize it through the adoption of the Religious Code or Code on Religious Organizations, which will sort out all the State and religious relations.

In general, there are positive trends in transformation in the religious sphere, but in order to achieve the main objectives, in the nearest future, it is necessary to work out and adopt a comprehensive strategy for the development of State and religious relations in the Russian Federation. This Strategy should reflect the balance of legislation and promote efficiency and stability in the development of canon law. The creation of civilized mechanisms for the Statereligious relations in our country depends on how quickly and competently these innovations are implemented in the Russian Federation.

\section{Conclusion}

The State and Church relations are, by their nature, one of the State's policies in the area of citizens' religious outlook - in essence, confessional State policy, which is one of the directions of State development. The Russian Constitution, adopted in 1993, established the legal basis for legislation on freedom of conscience and religious organizations. It stated, in effect, that the democratic essence of the State is based on the diversity of political institutions, ideologies and opinions, while the ideology of political parties, religious or other public associations and social groups cannot be established as binding for citizens.

The confessional policy in Russia began to take shape with the adoption of the Russian Constitution and Federal Law No. 125-FZ (1997). It reflected an attempt to bring the right of citizens to freedom of religion in line with the international legal covenants on human rights: the Universal Declaration of Human Rights, the Charter of Paris for a New Europe, the UN General Assembly Declaration on the Elimination of All Forms of Intolerance and 
Discrimination Based on Religion or Belief. Every citizen was given the opportunity to determine his or her own attitude towards religion, i.e. freedom of conscience.

\section{References}

Alontseva, D.V. (2019). The Church and the State in the Catholic tradition: a dominant model of relationships. The Gerald of the Southwest State University. Series: History and Law, 9(30), 16-23.

Alontseva, D.V., Safronova, E.V. (2011). The Problem of Relationship between the Church and the State in the Creative Heritage of S.N. Bulgakov. Law and Policy, 3, 463-472. https://www.nbpublish.com/library_read_article.php?id=-14169

Ilyin, I.A. (1993). The Lone artist. Articles, speeches, lectures. Moscow.

John Paul II. (1991) Encyclopedia Centessimusannus. Retrieved from https://www.fjp2.com/ru/john-paul-ii/online-library/encyclicals

Mantilla, L.F. (2019). Feed the Church, starve the party? Church-State relations and religious political mobilisation in 21 Catholic-majority countries. Religion, State and Society, 47(1), 87-103. DOI: 10.1080/09637494.2018.1533296

Nikolin, A. (1997). The Church and the State (The History of Legal Relations). Moscow.

Novikov, O.A. (2009). Byzantine concept of relations between the Church and the State. Voronezh: Origins.

Otter, G.A. (2014). On the conceptual foundations of the religious situation. Retrieved from http://cinref.ru/razdel/01200filosofia/08/89229.htm

Patriarch Kirill. (2012). Address of his Holiness the Patriarch of Moscow and all Russia on February 1 "Orthodoxy and the world". Retrieved from http://ruvek.ru/?module $=$ articles\&action $=$ view\&id $=6504$

Putin, V.V. (2012). Transcript of Russian Prime Minister Vladimir Putin's meeting with his Holiness Patriarch Kirill and leaders of traditional religious communities in Russia on February 08. Retrieved from http://www.patriarchia.ru/db/text/2005767.html

RerumNovarum (1991). 100 years of Christian social doctrine. Moscow: House of Mary.

Salygin, E.N. (1999). The Theocratic State. Publications of the Moscow Public Science Foundation on the Internet. Retrieved from http://www.mpsf.org

Strashoon, B.A. (2005). Constitutional (State) law of foreign countries. General part: Textbook for High Schools. Moscow.

The Constitution of Egypt. (2018). Retrieved from http://worldconstitutions.ru/?p=1013

The Constitution of Malta. (2013) Retrieved from https://vassallohistory.files.wordpress.com/2013/04/constitution.pdf

The Constitution of the Republic of Poland (2018). Retrieved from 


\section{https://legalns.com/download/books/cons/poland.pdf}

The Federal Law No. 125-FZ. (1997). On Freedom of Conscience and on Religious Associations. SPS “Consultant Plus”.

Tkachenko, Y.V. (2000). The State and the Church in the History of France and Russia. Moscow.

Tsypin, V. (2001). Episcopal jubilee Cathedral of the Russian Orthodox Church August 13-16. Orthodox encyclopedia. Moscow: Church research Center.

Vasilevich, G.A., Kondratovich, N.M., and Prikhodko, L.A. (2006). Constitutional law of foreign countries: Textbook. Meganewton: Book House.

Vydrina, G.A. (2018). On the conceptual foundations of the religious situation. Retrieved from http://cinref.ru/razdel/01200filosofia/08/89229.htm.

White, S. (2019). Race, Religion, and Obama in Appalachia. Social Science Quarterly, 100(1), 38-59. https://onlinelibrary.wiley.com/doi/abs/10.1111/ssqu.12550

Zapalsky, G.M. (2013). Spiritual Crisis in Russia and its Depth. Retrieved from http://www.runivers.ru/philosophy/logosphere/471979/ 